\title{
SURFACE TREATMENT OF STEEL AND VERIFICATION THE PRODUCTION LINE, WHICH IS HANDLED HELP BY SIMULATION
}

\author{
${ }^{1}$ Marek KLIMENT, ${ }^{2}$ Peter TREBUŇA, ${ }^{3}$ Marek MIZERÁK \\ 1, 2, 3 Technical University of Košice, Faculty of Mechanical Engineering, Department of Management, \\ Industrial and Digital Engineering, Slovak Republic, EU, marek.kliment@tuke.sk, peter.trebuna@tuke.sk
}

https://doi.org/10.37904/metal.2019.993

\begin{abstract}
The paper deals with steel surface treatment, blackening and phosphating of zinc and a production line that will perform these treatments. With the help of simulations were validated its various options and variants in which is able to work and produce. A variant has been developed for each surface treatment, as well as the simultaneous execution of both surface treatment at the same time. The paper describes both surface treatments, their types and then the line that will deal with these surface treatments in the production conditions. Surface treatments are divided into two groups. One group is the division of steel blackening methods. The second group describes the possibilities and types of phosphating. With the help of the simulation, the individual production variants for individual modifications as well as the concurrent model of the implementation of both surface treatments and the evaluation of the effectiveness of individual variants were revised. At the same time, the need to occupancy the production line with employees in individual variants and their benefits is also evaluated. We used the Tecnomatix Plant Simulation software module to create the simulation.
\end{abstract}

Keywords: Surface treatment, simulation, blackening, phosphating

\section{INTRODUCTION}

The surface treatment of machinery parts is a very frequent requirement of customers in manufacturing companies dealing with chip machining. However, the customer must specify exactly what surface finish he or she is interested in. Whether mechanical surface treatment, chemical coating, plating, coating coatings and the like. A relatively frequent requirement, especially for parts intended to fulfill certain aesthetic properties, is the requirement for black finish. This surface treatment is often used mainly in parts in the arms industry, but also in other parts that require some adjustment of their surface for the needs of aesthetic appeal as well as functional properties. Another very common requirement is phosphating of zinc coating. This treatment is very often required for components that need to at least partially eliminate the corrosive effects of the environment, for example, in the interior of the multi-plate brake discs and the like. This treatment is often required to improve the properties of steel to bind with other layers of paint, coatings and other surface treatments. The paper describes the possibilities of blackening steel. It also deals with the phosphating of steels and its applications $[2,5]$. In a row, it describes the design of a line for carrying out these surface treatments in business practice on smaller and larger machine parts.

\section{SURFACE TREATMENT OF METALS}

In the following chapter, some of the coatings that are related to the company's manufacturing program are described in more detail.

\subsection{Alkaline blackening of steels}

Alkaline blackening of steel materials is a proven process among steel surface treatment (Figure 1). This process is also known as hot blackening. It is a method of coloring steel products to ensure the appearance, 
abrasion and corrosion resistance of such machined parts in combination with adequate preservatives to support this treatment and extend its life. Technically, the means of blackening the hot alkali reaches a conversion of iron oxide layer. The process involves the application of thin oxide layers composed of mixed oxides ( $\mathrm{FeO}$ and $\mathrm{Fe} 3 \mathrm{O} 4$ ) by immersion in a solution of acids, hydroxides or hot alkaline melt, for example a mixture of sodium hydroxide and sodium nitrite. This production process is also referred to as noble rust. In contrast to the conventional ( $\mathrm{Fe} 2 \mathrm{O} 3$ ), which is peeling from the parent metal, the oxides formed on the metal remain alkaline blackening and prevent further oxidation. This treated surface is treated with a layer of preservative oil or varnish. This refined surface is achieved through a series of basic steps: Degreasing products, pickling, preheating and the blackening process itself. In the manufacturing process, it is necessary to maintain the required fluid temperatures, ranging from 55 to about $142{ }^{\circ} \mathrm{C}$, depending on the operation [5].

Advantages of Alkaline Blackening:

- improves the appearance of parts,

- increases abrasion resistance and improves corrosion resistance in combination with suitable impregnating oils,

- the dimensions of the treated parts do not change, the coating applied reaches a thickness of 0.5 to 2.5 $\mu \mathrm{m}$,

- $\quad$ long-term durability of the treated surface in a suitable treatment method.

Disadvantages of alkaline blackening:

- $\quad$ need for heating solutions,

- $\quad$ the tubs in which the individual processes are carried out are precisely specified,

- $\quad$ worse handling of parts immediately after the process is completed.

Applying alkaline blackening in practice:

- weapons production,

- manufacture of measuring instruments,

- binoculars production

- $\quad$ engineering industry, etc.

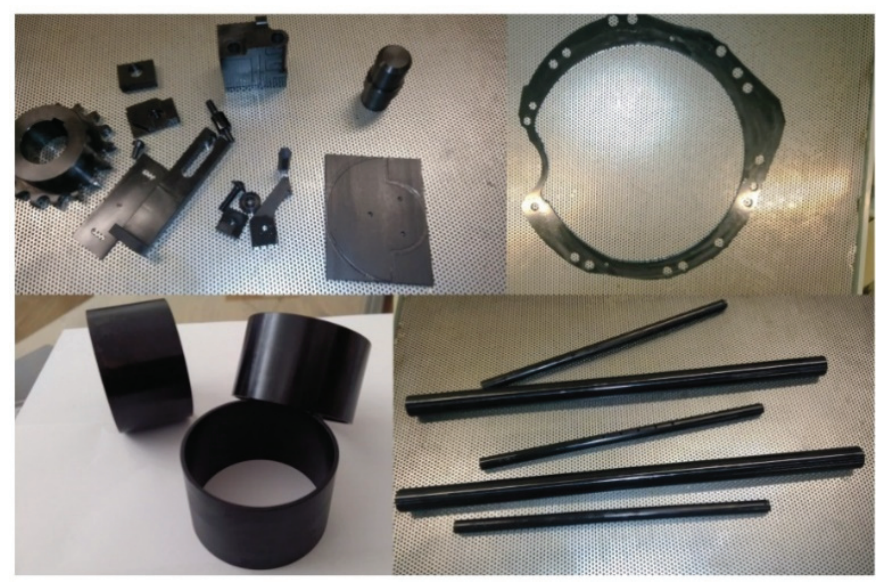

Figure 1 Components after alkaline blackening

\subsection{Phosphating of zinc}

Metal Finishing otherwise also known as parkerization or bonderization. It is a chemical surface treatment of metals that creates corrosion coatings, minimizes surface friction and improves abrasion resistance (Figure 2). These coatings are electrically non-conductive, resulting in a reduction in the corrosion current. In this chemical 
process, an insoluble crystalline layer of phosphates and zinc is formed, which is neither soluble in water nor in organic solvents, thus having a very good adhesion to the parent metal and thus providing a prerequisite for better adhesion of paints of various kinds. It is also possible to preserve the phosphate layer itself with a preservative oil, but this surface provides the possibility of good bonding of coatings, waxes, lubricants which reduces friction, lacquer and the like.

Advantages phosphate of zinc layer [5]:

- corrosion protection of metals,

- $\quad$ improving sliding properties,

- $\quad$ serves as an insulator,

- the ability to bind another layer of adhesives to each other,

- $\quad$ suitable for subsequent mechanical treatments (pressing, cutting, pulling, etc.),

- $\quad$ protective layer approx. $2 \mu \mathrm{m}$ thick.

Applying phosphating in practice:

- $\quad$ surface protective layer of brake components,

- gearwheel surface protection for running gear systems,

- a more durable alternative to primer for the next dyeing process.

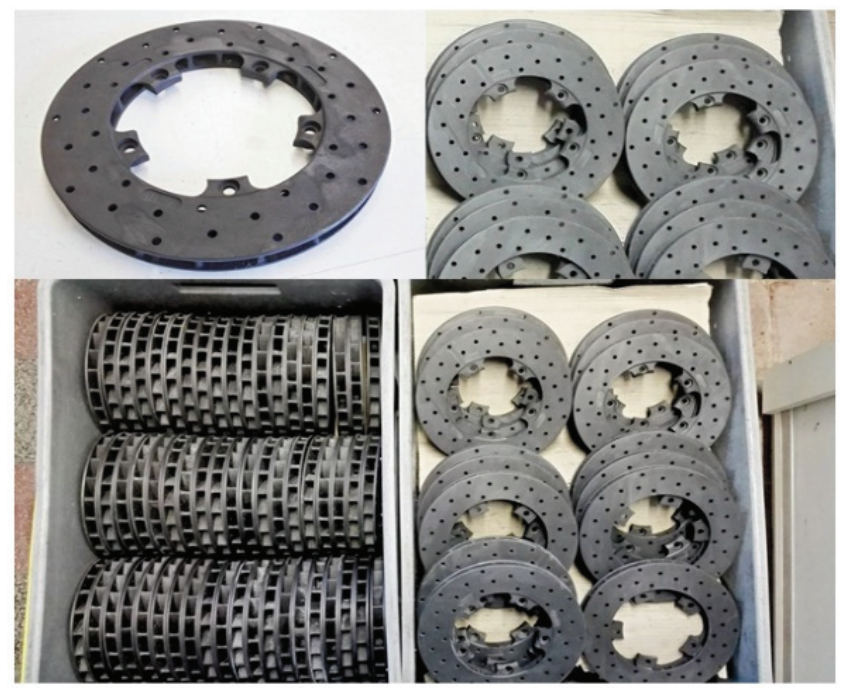

Figure 2 Components after a phosphating of zinc

\section{SURFACE TREATMENT LINE FOR ALKALINE BLACKENING AND PHOSPHATING OF ZINC}

In order to realize these surface treatments and provide them as a service to business customers, it is necessary to build a line where these activities can be realized. To realize this business interest, it is essential to comply with all legislative standards that are subject to laws and standards. In addition, it is necessary to develop project documentation with all the necessary elements. However, in order to know in advance, the potential of its intention and to identify its production capacities and the needs of the number of new employees, we have decided to develop several versions of simulation models that will help us to realize the intention. Tecnomatix Plant Simulation software module was used to develop these models [1,7]. When creating simulation models, we need to take into account some of the characteristics of manufacturing processes and the individual times that need to be observed when creating surface treatments $[3,6]$. One of the conditions that must be followed is the sequence of production. To save space in the production hall, we decided to place 
both finishes on one line. This is possible because these surface treatments are very similar in many ways. Figure 3 shows the arrangement of the tubs with solutions for the formation of both surface treatments [8,9].
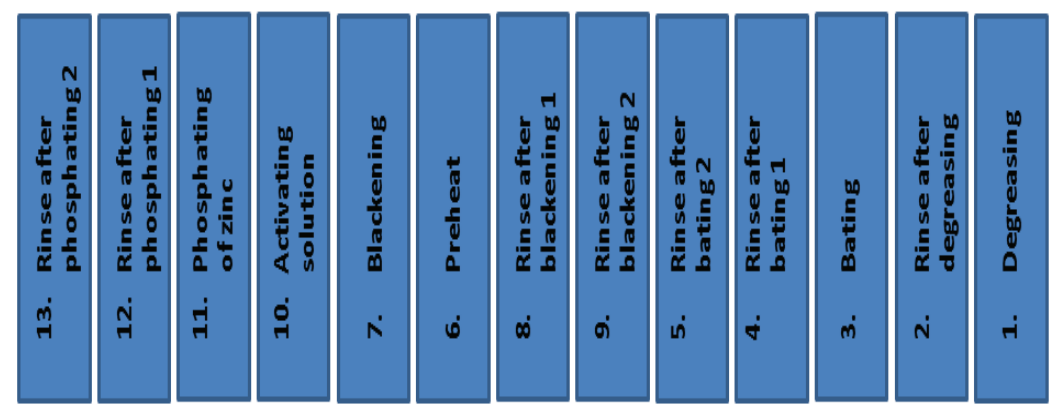

Figure 3 Arrangement of tubs with surface treatment solutions

Another condition is to keep the times, the individual steps in creating these finishes. Table 1 shows a list of prescribed operations for the alkaline blackening manufacturing process as well as the individual step times.

Table 1 Manufacturing operations for alkaline blackening

\begin{tabular}{|l|l|l|l|}
\hline Order & Temperature & Time & Production description \\
\hline & & $10 \mathrm{~min}$. & Input and preparation of input material \\
\hline Tubs no. 1 & $55-99^{\circ} \mathrm{C}$ & $1-6 \mathrm{~min}$. & Degreasing of parts \\
\hline Tubs no. 2 & ambient temp & $30 \mathrm{sec}$. & Rinse after degreasing \\
\hline Tubs no. 3 & $15-30^{\circ} \mathrm{C}$ & $5-15 \mathrm{~min}$. & $\begin{array}{l}\text { Bating of the solution } 15 \% \mathrm{HCl} \text {, removal of corrosion } \\
\text { residues }\end{array}$ \\
\hline Tubs no. 4 & ambient temp & $30 \mathrm{sec}$. & Rinse after batingno.1 \\
\hline Tubs no. 5 & ambient temp & $30 \mathrm{sec}$. & Rinse after batingno. 2 \\
\hline Tubs no. 6 & $60-70^{\circ} \mathrm{C}$ & $3-5 \mathrm{~min}$. & Preheat \\
\hline Tubs no. 7 & $135-142{ }^{\circ} \mathrm{C}$ & $\begin{array}{l}12-20 \\
\text { min }\end{array}$ & $\begin{array}{l}\text { Blackening, time and temperature depends on the material } \\
\text { composition of the parts }\end{array}$ \\
\hline Tubs no. 8 & ambient temp & $30 \mathrm{sec}$. & Rinse after blackeningno. 1 \\
\hline Tubs no. 9 & ambient temp & $30 \mathrm{sec}$. & Rinse after blackeningno. 2 \\
\hline & & & $\begin{array}{l}\text { Drying and subsequent applying of parts with preservative } \\
\text { oil, subsequent packaging of finished products }\end{array}$ \\
\hline
\end{tabular}

Table 2 shows the steps that need to be followed to form the phosphating of zinc coating.

Table 2 Production operations for phosphating of zinc

\begin{tabular}{|l|l|l|l|}
\hline Order & Temoperature & Time & Production description \\
\hline & & $10 \mathrm{~min}$. & Input and preparation of input material \\
\hline Tubs no. 1 & $55-99^{\circ} \mathrm{C}$ & $1-6 \mathrm{~min}$. & Degreasing of parts \\
\hline Tubs no. 2 & ambient temp & 30 sek. & Rinse after degreasing \\
\hline Tubs no. 3 & $15-30^{\circ} \mathrm{C}$ & $5-15 \mathrm{~min}$. & $\begin{array}{l}\text { Bating of the solution } 15 \% \mathrm{HCl} \text {, removal of corrosion } \\
\text { residues }\end{array}$ \\
\hline Tubs no. 4 & ambient temp & 30 sek. & Rinse after batingno.1 \\
\hline Tubs no. 5 & ambient temp & 30 sek. & Rinse after batingno.2 \\
\hline Tubs no. 10 & $15-30^{\circ} \mathrm{C}$ & $3-5 \mathrm{~min}$. & Activating solution \\
\hline Tubs no. 11 & $65-70^{\circ} \mathrm{C}$ & $3-5 \mathrm{~min}$ & Phosphating of zinc \\
\hline Tubs no. 12 & ambient temp & 30 sek. & Rinse after phosphatingno. 1 \\
\hline Tubs no. 13 & ambient temp & 30 sek. & Rinse after phosphatingno.2 \\
\hline & & & Drying and subsequent packaging of finished products \\
\hline
\end{tabular}

\subsection{Simulation model of line for independent alkaline blackening process}

Alkaline Blackening: This manufacturing process consists of 9 tubs with chemical solutions and water rinses (Table 1). Of which are tubs with chemical solutions are heated to temperatures that are necessary for their proper performance. It is a bath no. 1 degreasing, bath no. 6 with preheating and bath no. 7 with blackening chemical solution. As is evident from the process (Table 1, 2) as well as the schematic representation of the 
line of arrangement of the individual baths (Figure 3), both surface treatments are flargely similar. They differ in the main part, which performs the desired effect on the surface of the part. Obviously, the alkaline blackening process is time consuming [3,9]. The main operation takes 20 minutes. In contrast, the main phosphating of zinc process takes 5 minutes. We have created simulation models of both manufacturing processes. Each individually for one full working day, that is, two working changes.

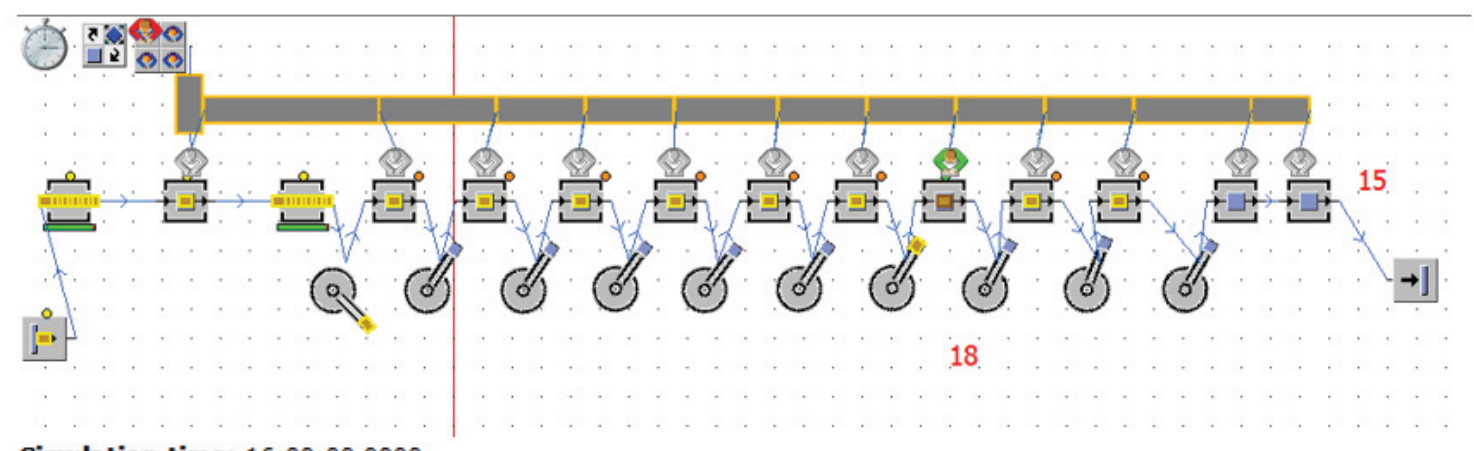

Simulation time: 16:00:00.0000

Cumulated Statistics of the Parts which the Drain Deleted

\begin{tabular}{|l|r|r|r|r|r|r|r|r|}
\hline Object Name & Mean Life Time & Throughput & TPH & Production & Transport Storage Value added & Portion \\
\hline Drain & Entity & $9: 49: 20.2543$ & 15 & 1 & $67.27 \%$ & $10.83 \%$ & $21.90 \%$ & $10.94 \%$ \\
\hline
\end{tabular}

Figure 4 Simulation model of alkaline blackening

As can be seen from the simulation model and the cumulative statistically total manufactured products (Figure 4) during one production day, the line will generally complete 15 production doses of alkaline blackening. The value-added rate set by the Tecnomatix Plant Simulation simulation software is $10.94 \%$. It is necessary to employ two employees for the efficient operation of the line in this form $[8,10]$. First employment will provide component preparation for entry into the production process and subsequent packaging components afterwards. The second worker will provide for the operation of the gantry crane, which will assist in moving the products between the individual tubs with the chemical solutions [12,14].

\subsection{Simulation model of line for independent phosphating of zinc process}

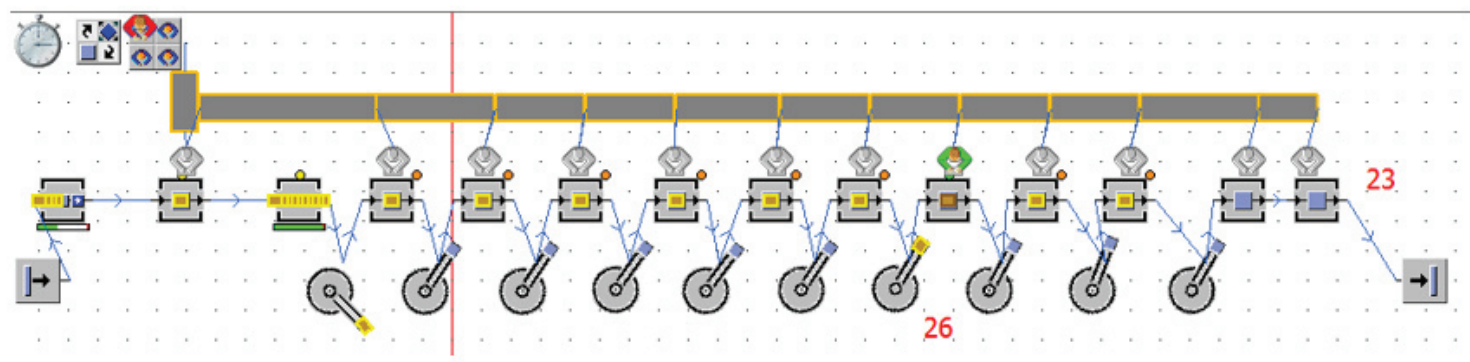

Simulation time: 16:00:00.0000

Cumulated Statistics of the Parts which the Drain Deleted

\begin{tabular}{|l|r|r|r|r|r|r|r|r|}
\hline Object Name Mean Life Time Throughput TPH Production Transport Storage Value added & Portion \\
\hline Drain Entity & $9: 05: 33.7343$ & 23 & 1 & $55.60 \%$ & $9.05 \%$ & $35.36 \%$ & $8.98 \%$ & \\
\hline
\end{tabular}

Figure 5 The simulation model for phosphating of zinc

Figure 5 shows a simulation model of the phosphating of zinc process. Due to less time consuming in this process within one business day completing 23 production doses. Value added is $8.98 \%$ in this manufacturing 
process according to Tecnomatix Plant Simulation statistics. As in the previous models, two employees are needed to secure the production process [11,12].

\subsection{Simulation model of the surface treatment line in the concurrently running of both surface treatments}

In the alternate mode of production, it is difficult to meet the frequent customer demand for express surface treatment. This type of finish means that the customer will agree on a specific term during which he or she wants to perform the ordered surface finish while waiting, possibly in the shortest possible time. This means that if the requirement for alkaline blackening is phosphating of zinc at the same time, it takes at least 2 working days depending on the size of the production batch to meet this requirement. If this requirement is met, fluency in one of the production processes is disrupted. This means that if I want to do both finishes at one time, it is necessary to interrupt one surface treatment, do another, and then go back to the previous finish. For this reason, we have also decided to propose a variation in which the line would be able to simultaneously carry out both surface treatments at the same time (Figure 6). However, it is necessary to take into account the more expensive model, where the monorail gantry crane is not sufficient, so it is necessary to extend it to another track with a chain block. In this design, each coating has its own crane to handle the material during production. This extension of the crane entails the requirement for the reception of another worker, who will be responsible for the operation of the second crane. This will ensure the continuity of both production processes $[4,7]$.

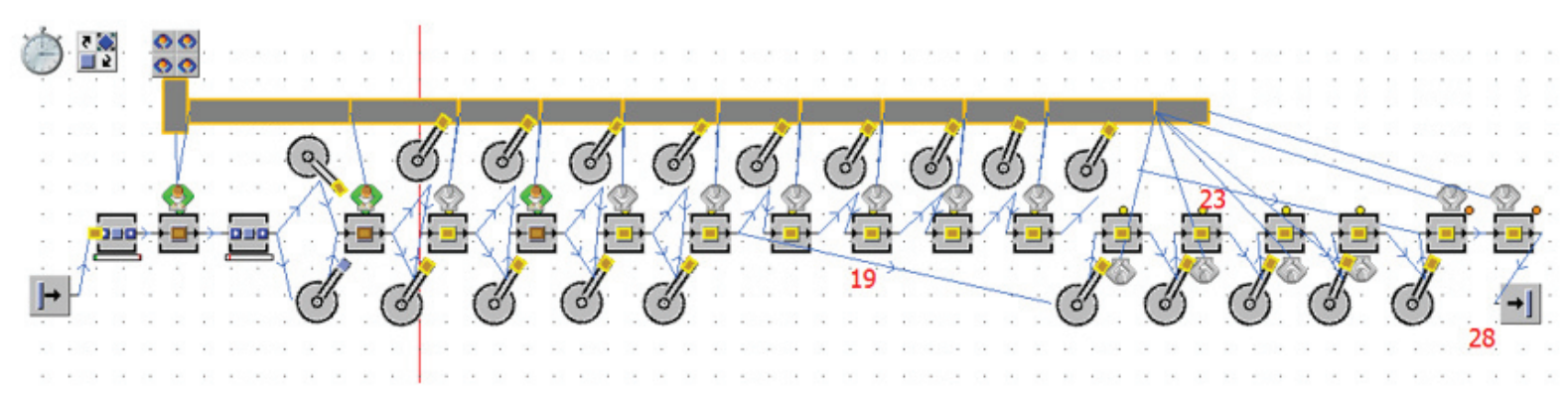

Simulation time: 16:00:00.0000

Cumulated Statistics of the Parts which the Drain Deleted

\begin{tabular}{|l|r|r|r|r|r|r|r|r|}
\hline Object Name Mean Life Time Throughput TPH Production & Transport Storage Value added & Portion \\
\hline Drain Entity & $7: 54: 39.6429$ & 28 & 2 & $45.12 \%$ & $23.12 \%$ & $31.76 \%$ & $11.76 \%$ & \\
\hline
\end{tabular}

Figure 6 Simulation model of simultaneous operation of both surface treatments

From the simulation model of the design of the unification of production processes into the concurrent process, it follows that during two changes in one working day the line simultaneously produces a total of 28 production doses in the final form. Looking at the partial counters that are set to the main manufacturing processes in both finishes, it is visible that the line is processing 19 production doses of alkaline blackening and 23 doses of phosphating of zinc. Consequently, 14 production batches will remain in progress for the next business day. The total added value of the concurrent line operation is $11.76 \%$.

\section{CONCLUSION}

From the point of view of line efficiency and utilization, it seems to be the best option to design version 3 , in which production can take place in concurrently. From the point of view of the costs incurred for the implementation of such a design, it is necessary in this variant to take into account the higher costs of the 
gantry crane as well as the need for more service. In this model, it is necessary to employ 3 operators for each line change in which the line will work for the effective line operation.

\section{ACKNOWLEDGEMENTS}

This article was created by implementation of the grant project VEGA 1/0708/16 Development of a new research methods for simulation, assessment, evaluation and quantification of advanced methods of production and APVV-17-0258 Digital engineering elements application in innovation and optimization of production flows.

\section{REFERENCES}

[1] BANGSOW, S. Tecnomatix Plant Simulation. Modeling and Programming by means of examples. Springer. 2015.

[2] J EDL, M., LERHER, T., ROSI, B. Energy efficiency model for the mini-load automated storage and retrieval systems. International Journal of Advanced Manufacturing Technology, 2013, pp. 1-19.

[3] STRAKA, M., MALINDZAK, D. Algorithms of capacity balancing of printing machineries for Alfa Foils, a.s. planning system. Acta Montanistica Slovaca, 2009, vol. 14, no. 1, pp. 98-102.

[4] BÁRDY, M., KUDRNA, J., ŠRÁMKOVÁ, B.B., EDL, M. Interactive game supporting SMED method. Applied Mechanics and Materials, 2014, pp. 141-146.

[5] SANIUK, S., SAMOLEJOVA, A., SANIUK, A., LENORT, R. "Benefits and barriers of participation in production networks in a metallurgical cluster - research results.", Metalurgija, 2015, vol. 54, no. 3, pp. 567-570.

[6] ROSOVA, A., MALINDZAKOVA, M. Material flow - starting point for recovery of inputs in the production company. International Multidisciplinary Scientific GeoConference Surveying Geology and Mining Ecology Management, SGEM 3(5), 14th International Multidisciplinary Scientific Geoconference and EXPO, SGEM Albena; Bulgaria, 2014.

[7] WICHER, P., STAŠ, D., KARKULA, M., LENORT, R., BESTA, P. A computer simulation-based analysis of supply chains resilience in industrial environment. Metalurgija, 2015, vol. 54, no. 4, pp. 703-706.

[8] Tecnomatix Plant Simulation Basics, Methods and Strategies Student Guide, 2012, Siemens PLM.

[9] KLOS, S., PTALAS-MALISZEWSKA, J. Badania kluczowych problemów w zarządzaniu utrzymaniem ruchu, W: Innowacje w zarządzaniu i inżynierii produkcji / red. R. Knosala. T. 2.- Opole: Oficyna Wydaw. Polskiego Towarzystwa Zarządzania Produkcją, 2014, pp. 678-687.

[10] STRAKA, M., LENORT, R., KHOURI, S., FELIKS, J. „Design of large-scale logistics systems using computer simulation hierarchic structure", International Journal of Simulation Modelling, 2018, vol. 17, no. 1, pp. 105-118.

[11] STRAKA, M., KHAORI, S., ROSOVA, A., CAGANOVA, D., CULKOVA, K. Utilization of computer simulation for waste separation design as a logistics system, International Journal of Simulation Modelling, 2018, vol. 17, no. 4, pp. 583-596.

[12] POÓR, P., KUCHTOVÁ, N., ŠIMON, M. Machinery Maintenance as Part of Facility Management. 24TH DAAAM INTERNATIONAL SYMPOSIUM ON INTELLIGENT MANUFACTURING AND AUTOMATION. Procedia Engineering, Zadar, 2014, vol. 69, pp. 1276-1280.

[13] POÓR, P., ŠIMON, M., KARKOVÁ, M. CMMS as an effective solution for company maintenance costs reduction. Production Management and Engineering Sciences, 2015, pp. 241-246.

[14] TREBUNA, P., PEKARCíKOVA, M., EDL, M. Digital value stream mapping using the Tecnomatix Plant Simulation software. International Journal of Simulation Modelling = IJSIMM. - Wolkersdorf im Weinvierte, DAAAM International Vienna. vol. 18, no. 1, 2019, pp. 19-32. 